\title{
PROBLEMATIKA PEMBELAJARAN UNTUK ANAK BERKEBUTUHAN KHUSUS PADA MASA PANDEMI COVID-19 DI SEKOLAH INKLUSI DAN STRATEGI MENANGANINYA
}

\author{
Narullyta Puspita Dewi \\ Pendidikan Khusus, Fakultas Pendidikan, Universitas Negeri Jakarta \\ narullytapd@gmail.com \\ Nurul Fadilah, Solehawati Rahma \\ Pendidikan Khusus, Fakultas Pendidikan, Universitas Negeri Jakarta \\ fnuruladilah30@gmail.com, solehawatirahma@gmail.com
}

\begin{abstract}
Abstrak
SDN Kramat Jati 16 Pagi sudah mulai melaksanakan pembelajaran jarak jauh (daring) di masa pandemi ini. Disamping mematuhi keputusan pemerintah Indonesia terkait program pembatasan sosial berskala besar, tetap melaksanakan penyelenggaraan kegiatan pembelajaran jarak jauh (daring) ini merupakan pilihan yang tepat, apabila memaksakan sistem pembelajaran tatap muka langsung, maka rawan bagi kesehatan peserta didik berkebutuhan khusus. Dengan kegiatan pembelajaran jarak jauh ini, peserta didik berkebutuhan khusus tetap mendapatkan pembelajaran dan terjaga kesehatannya di bawah pengawasan orang tua masing-masing. Metode penulisan artikel menggunakan metode narasi melalui kegiatan wawancara. Subjek yang digunakan berjumlah dua orang, yakni seorang guru dan salah satu orang tua peserta didik. Waktu dan tempat pengumpulan data dilakukan dengan waktu yang fleksibel dan secara jarak jauh. Berdasarkan hasil wawancara, problematika pembelajaran untuk anak berkebutuhan khusus pada masa pandemi Coronavirus Disease 2019 (COVID-19) di sekolah inklusi, yaitu; 1) kurang siapnya guru dan orangtua dalam pembelajaran jarak jauh ini, 2) kurangnya keterampilan orangtua dalam mengakses internet, 3) rasa bosan yang muncul pada anak sehingga membuat anak malas untuk melakukan pembelajaran jarak jauh ini.
\end{abstract}

Kata Kunci : Problematika pembelajaran, anak berkebutuhan khusus, masa pandemi, sekolah inklusi, strategi.

\section{PENDAHULUAN}

Pada bulan Desember, di akhir tahun 2019, telah ditemukan sebuah virus baru yaitu corona virus jenis baru (SARS-CoV-2) dan penyakitnya disebut Coronavirus Disease 2019 (COVID-19). Diketahui, virus ini pertama kali ditemukan di daerah Wuhan, Tiongkok, Cina yang akhirnya meluas hingga ke seluruh dunia. World Health Organization (WHO) menetapkan virus yang sedang merebak ini disebut sebagai pandemi. 
Coronavirus Disease 2019 (COVID-19) merupakan penyakit menular yang dapat menular melalui percikan cairan saat batuk, bersin, atau bersalaman yang keluar dari hidung atau mulut orang yang telah terinfeksi virus Coronavirus Disease 2019 (COVID-19). Percikan cairan virus Coronavirus Disease 2019 (COVID-19) yang keluar melalui mulut atau hidung orang yang terinfeksi bisa menempel pada permukaan benda-benda sekitar seperti di atas meja, gagang pintu, tombol lift dan lain-lain. Apabila percikan cairan tersebut tersentuh dan masuk ke dalam tubuh manusia melalui mata, mulut, atau hidung maka dapat dipastikan orang tersebut akan positif terinfeksi Coronavirus Disease 2019 (COVID-19).

Pergerakan kurva kasus Coronavirus Disease 2019 (COVID-19) terlihat terus bertambah hingga saat ini (dapat dilihat di Coronavirus updates www.worldmeters.info/coronavirus/), sehingga pemerintah yang ada di seluruh dunia dengan tanggap dan sepakat mengambil keputusan untuk melakukan penguncian wilayah. Hal ini dilakukan sebagai salah satu cara untuk mengurangi penyebaran virus yang lebih luas lagi. Di Indonesia, pemerintah tidak langsung mengambil keputusan untuk menerapkan penguncian wilayah namun menerapkan pembatasan interaksi sosial yang kemudian dibagi lagi menjadi lebih khusus yaitu pembatasan sosial berskala besar untuk di wilayah-wilayah yang termasuk kategori zona merah.

Kemunculan virus tersebut sangat berdampak pada kehidupan kita saat ini, karena telah memakan banyak korban jiwa dan merugikan serta menghambat kelancaran beroperasi banyak bidang, salah satunya ialah bidang pendidikan. Tak hanya di Indonesia, lembaga pendidikan di seluruh dunia serentak untuk tidak melaksanakan pembelajaran secara tatap muka langsung. Penyelenggaraan pendidikan secara tatap muka langsung di Indonesia terpaksa diberhentikan oleh pemerintah sebagai salah satu upaya mengurangi penularan virus tersebut. Oleh karena itu, saat ini penyelenggaraan pendidikan di Indonesia dilaksanakan dengan pembelajaran jarak jauh (daring).

Akibat dari kondisi yang mendadak berubah menjadi seperti sekarang, banyak lembaga pendidikan yang terpaksa harus siap dan tetap menyelenggarakan pendidikan dengan pembelajaran jarak jauh (daring), tak heran jika beberapa lembaga sekolah terlihat mengalami kesukaran untuk beradaptasi dengan keadaan. Adanya perubahan sistem pembelajaran ini, menyebabkan munculnya problematika pada keberlangsungan pembelajaran yang dilakukan dengan jarak jauh (daring), baik di lembaga pendidikan tingkat rendah hingga atas. Bagi beberapa pihak terkait, pembelajaran jarak jauh (daring) ini cukup menyulitkan karena dipengaruhi oleh beberapa faktor. Ada beberapa faktor, diantaranya yaitu, peserta didik, materi, waktu, proses pembelajaran, ketersediaan teknologi dan finansial. Hal ini berdampak pada lembaga pendidikan reguler, namun yang menjadi sorotan bukan status lembaga pendidikan yang reguler atau tidak, melainkan lembaga pendidikan yang menampung peserta didik berkebutuhan khusus yang biasa dikenal sekolah inklusi. 
Sebagai salah satu contoh sekolah inklusi yang sudah menjalani pembelajaran jarak jauh (daring), yakni SDN Kramat Jati 16 Pagi yang berada di kawasan Jakarta Timur. Bagi SDN Kramat Jati 16 Pagi, kondisi seperti ini sangat berpengaruh dalam keberlangsungan proses penyelenggaran pendidikan, karena seperti yang diketahui peserta didik berkebutuhan khusus membutuhkan pembelajaran dan penanganan secara langsung, tak terkecuali anak berkebutuhan khusus apapun. Oleh karena itu, dibutuhkan strategi khusus untuk menanganinya dan orang tua berperan utama pada masa pandemi ini sangat berperan besar guna membantu keberlangsungan pembelajaran jarak jauh (daring) untuk anak berkebutuhan khusus di rumah.

\section{METODE PENELITIAN}

Pada penulisan artikel ini, penulis menggunakan metode narasi melalui kegiatan wawancara. Menurut Webster dan Metrova, metode narasi merupakan kemampuan untuk memahami identitas dan pandangan dunia seseorang dengan mengacu pada cerita-cerita (narasi) yang ia dengarkan ataupun tuturkan di dalam aktivitasnya sehari-hari. ${ }^{1}$ Metode ini digunakan karena menurut penulis keaslian data dapat dipertanggungjawabkan karena didapatkan langsung dari seseorang yang mengalami langsung kejadian tersebut. Subjek yang digunakan berjumlah dua, yakni seorang guru dan salah satu orang tua peserta didik. Kedua subjek ini digunakan karena keterbatasan jumlah narasumber. Waktu dan tempat pengumpulan data dilakukan dengan waktu yang fleksibel dan secara jarak jauh (daring). Teknik pengumpulan data melalui wawancara yang dilakukan oleh seluruh penulis dengan memberikan pertanyaan semi terstruktur kepada narasumber. Narasumber pada penulisan artikel ini, yaitu seorang guru yang bekerja di SDN Kramat Jati 16 Pagi dan salah satu orang tua peserta didik berkebutuhan khusus yang bersekolah di SDN Kramat Jati 16 Pagi.

\section{HASIL DAN PEMBAHASAN}

Berdasarkan hasil wawancara dengan kedua narasumber yang didapatkan oleh penulis, penulis dapat memaparkan bahwa SDN Kramat Jati 16 Pagi sudah mulai melaksanakan pembelajaran jarak jauh (daring) di masa pandemi ini. Disamping mematuhi keputusan pemerintah Indonesia terkait program pembatasan sosial berskala besar, tetap melaksanakan penyelenggaraan kegiatan pembelajaran jarak jauh (daring) ini merupakan pilihan yang tepat, apabila memaksakan sistem pembelajaran tatap muka langsung, maka rawan bagi kesehatan peserta didik berkebutuhan khusus. Dengan kegiatan pembelajaran jarak jauh (daring) ini, peserta didik berkebutuhan khusus tetap mendapatkan pembelajaran dan terjaga kesehatannya di bawah pengawasan orang tua.

Di setiap sekolah diadakan pembelajaran jarak jauh (daring) tak terkecuali untuk sekolah inklusi, tentunya di sekolah inklusi terdapat anak berkebutuhan khusus yang jika pertemuan tatap 
muka saja diperlukan pemberian perhatian khusus. Dalam pembelajaran jarak jauh (daring) pun anak berkebutuhan khusus di sekolah inklusi tetap memerlukan perhatian khusus, untuk itu ada beberapa prosedur yang dilakukan dan perlu diperhatikan dalam pembelajaran jarak jauh (daring) ini menurut salah satu guru di sekolah inklusi yakni SDN Kramat Jati 16 Pagi, Bu Dwiyana mengatakan bahwa pada dasarnya semua peserta didik mempunyai kebutuhannya masing-masing, namun kebutuhan anak berkebutuhan khuus di sekolah inklusi perlu lebih diperhatikan.

Dalam melaksanakan pelaksanaan pembelajaran ini peserta didik perlu beradaptasi namun tetap harus meneruskan pembelajaran atau program yang telah dilaksanakan sebelumnya, tidak mudah namun dengan bantuan dan bimbingan dari guru pembelajaran ini dapat terlaksana dengan baik. Untuk peserta didik berkebutuhan khusus selain melaksanakan pembelajaran sesuai dengan materi yang tentunya sudah di modifikasi, peserta didik juga harus melaksanakan program kemandirian atau program pembelajaran individu (PPi).

Program pelaksanaan pembelajaran jarak jauh (daring) ini dilakukan melalui media online seperti menggunakan aplikasi tatap muka zoom, video call whatsapp, serta media offline yaitu tontonan yang sudah disediakan kementrian pendidikan dan budaya di salah satu saluran televisi Indonesia. Menurut Drago bahwa siswa belajar online lebih cenderung memiliki gaya belajar visual dan baca tulis yang lebih kuat. Biasanya tatap muka melalui aplikasi penyedia telepon video gratis dilakukan secara teratur mengikuti jadwal, kegiatannya akan didampingi orang tua peserta didik masing-masing. Hal ini seperti yang dikemukakan menurut Zapalska apabila seorang siswa tertentu belajar terbaik dengan cara tertentu, ia harus dihadapkan pada berbagai pengalaman belajar untuk menjadi pembelajar online yang lebih fleksibel.

Berdasarkan hasil wawancara kepada salah satu orang tua murid, Bunda Raffa mengatakan bahwa materi yang diberikan dalam pembelajaran jarak jauh (daring) ini cukup banyak hingga membuat orang tua cukup kebingungan untuk mengajari anaknya di rumah, ditambah jika ada tugas yang mengharuskan membeli barang-brang yang cukup banyak atau mengharuskan keluar rumah untuk membelinya, ini membuat orang tua merasa khawatir untuk pergi keluar rumah di masa pandemi seperti sekarang, pembelajaran jarak jauh (daring) juga berpengaruh kepada peserta didik, diungkapkan dari hasil wawancara bahwa anak terlihat tidak bersemangat ketika pembelajaran, hal ini wajar dikarenakan anak mulai bosan dan butuh berinteraksi secara langsung dengan temantemanya. Hal ini menjadi tantangan tersendiri bagi guru-guru di sekolah inklusi untuk terus menstimulus orangtua agar tetap semangat dan berkomitmen dalam membantu kesuksesan hasil belajar peserta didik masing-masing. 
Dalam pelaksanaan pembelajaran jarak jauh terdapat beberapa aspek yang perlu diperhatikan seperti:

1. Program bermakna

Menurut Muhaimin, dkk (2009) program adalah mencakup seluruh kegiatan yang berada di bawah unit administrasi yang sama, atau sasaran- sasaran yang saling bergantung dan saling melengkapi, yang semuanya harus dilaksanakan secara bersamaan atau berurutan. ${ }^{4}$ Program sering dikaitkan dengan perencanaan, persiapan, dan desain atau rancanagan. Hal ini berarti program bermakna dalam pelaksanaan jarak jauh dimaksudkan sebagai program terstruktur yang memiliki rencana kegiatan pembelajaran dengan tujuan meberikan sebuah pembelajaran terkait informasi baru pada konsep-konsep relevan yang terdapat dalam struktur kognitif seseorang, dimana pembelajaran ini akan memberikan sebuah manfaat bagi kehidupan peserta didik nantinya.

- Program yang menyesuaikan dengan kondisi lingkungan di rumah

- Program yang mempertimbangkan kebutuhan individual berdasarkan hasil asessmen yang telah dilakukan sebelumnya dan program yang telah berjalan namun disesuaikan kembali dengan kondisi rumah.

- Selain akademik, fokus juga kepada program yang melatih rutinitas dan keterampilan hidup sehari-hari, walaupun dirumah saja namun anak harus mampu mandiri dengan program pembelajaran individu yang telah diberikan orang tua hanya tinggal meneruskan program tersebut dirumah.

- Program yang tetap meningkatkan partisipasi semua peserta didik, seperti kerja kelompok atau proyek seni.

- Program belajar yang tetap memungkinkan adanya interaksi, antara guru, peserta didik, dan orang tua. 
2. Komunikasi

Aspek komunikasi menjadi sangat penting dalam melaksanakan pembelajaran jarak jauh (daring). Joko Yuwono (2012: 59) mendefinisikan komunikasi sebagai proses dimana individu dapat bertukar informasi dan menyampaikan pikiran serta perasaan, dimana ada pengirim pesan yang mengkodekan/memformulasikan pesan dan penerima mengkodekan pesan/memahami pesan. Agar pelaksanaan pembelajaran jarak jauh (daring) berjalan secara efektif, maka dibutuhkan komunikasi yang baik antara komunikator (pengirim pesan) dengan komunikasn (penerima pesan). Berikut hal yang perlu diperhatikan dalam aspek komunikasi untuk melancarkan pembelajaran jarak jauh:

a. Rancangan program atau ketentuan selama masa daring harus disampaikan kepada guru kelas dan orang tua sehingga program mampu berjalan sesuai dengan yang diharapkan.

b. Buat kesepakatan saling berempati dan apresiasi selama masa daring. Empati dan apresiasi sangant penting dalam masa daring ini, saling berempati antar guru pembimbing khusus, guru mata pelajaran dan orang tua siswa dan mengapresiasi hasil kerja peserta didik oleh orangtua dan guru.

c. Rutin berkomunikasi mengenai perkembangan peserta didik dari orangtua ke guru pembimbing khusus, untuk mengetahu kemajuan atau kesulitan yang dihadapi oleh orangtua selama membimbing anaknya belajar.

d. Monitoring pelaksanaan pembelajaran jarak jauh (daring), tanyakan kendala yang mungkin ditemui, dan bersama cari solusi terbaik.

3. Pengembangan diri

a. Mengacu kepada keterampilan aktivitas sehari-hari dan bina diri meliputi program pembiasaan di rumah tanpa gawai

b. Utamakan konsistensi dan menggunakan panduan taskanalysis

4. Modifikasi pengajaran

a. Konsultasikan ke guru pembimbing khusus atau orang tua mengenai kemampuan peserta didik yang mendapatkan prioritas atau perhatian lebih

b. Gunakan prinsip dasar modifikasi yaitu melakukan penyesuaian kurikulum agar semua peserta didik bisa terlibat

c. Gunakan rancangan pelaksanaan pembelajaran inklusi untuk pembelajaran tematik yang dimodifikasi agar mudah dipelajari oleh peserta didik berkebutuhan khusus. 


\section{Modifikasi kurikulum}

Modifikasi kurikulum dilakukan dengan mengubah beberap aspek, diantaranya:

a. Tujuan disederhanakan dengan mempertimbangkan kemampuan peserta didik berkebutuhan khusus saat ini.

b. Materi disederhanakan dan sebisa mungkin diarahkan ke life skill

c. Strategi harus mempertimbangkan kemampuan peserta didik berkebutuhan khusus (diskusi, pendampingan 1-1, instruks sederhana)

d. Teknologi yang adaptable dan accessible, diantaranya platform digital atau aplikasi di smartphone

e. Rekomendasikan media/alat peraga sebagai sumber belajar yang tersedia di rumah.

6. Fleksibel

a. Beri waktu tambahan untuk orang tua merespon kegiatan pembelajaran dengan mempertimbangan kondisi peserta didik, orang tua, dan lingkungan di rumah

b. Sediakan ruang konsultasi orang tua dan jadwalkan virtual meeting dengan peserta didik untuk mengakomodasi kebutuhan sosial emosional orangtua, dikarenakan dalam proses pembelajaran orang tua kesulitan da nada hal-hal yang tidak bisa ditangani orangtua sehingga membuat orang tuamerasa kewalahan bahkan stres membimbing anak mereka dalam belajar.

c. Rangkul orang tua untuk tetap berkomitmen bekerja sama selama pembelajaran jarak jauh (daring) dan mempersiapkan peserta didik kembali ke sekolah setelah keadaan dirasa sudah cukup baik

Secara keseluruhan, tantangan dalam pembelajaran jarak jauh (daring) bagi anak berkebutuhan khusus ialah sebagai berikut: 1) keterbatasan orang tua dalam memahami tugas, 2) keterbatasan sarana keterampilan di rumah, 3) kesulitan akses internet di rumah, 4) keterbatasan pemahaman orang tua dalam pemanfaatan teknologi informasi, 5) materi yang diberikan dalam pembelajaran jarak jauh (daring) ini cukup banyak, 6) Anak-anak mudah bosan. Hal tersebut dapat disimpulkan bahwa dalam menyelenggarakan pembelajaran untuk anak berkebutuhan khusus di sekolah inklusif dibutuhkan beberapa strategi dan peran beberapa pihak. Strategi yang dapat dilakukan selain program bermakna, komunikasi, pengembangan diri, modifikasi pengajaran, kefleksibilitasan dan modifikasi kurikulum ialah bagi guru harus mendetailkan apa yang harus dilakukan oleh orang tua terhadap anaknya. Guru juga harus mampu memberikan pedoman kepada orang tua dan sharing apapun yang dilakukan karena anak-anak belajar secara berkesinambungan. Selain itu, bagi orang tua sebaiknya bekerja sama dengan sekolah, mengikuti arahan dari sekolah, melakukan perubahan dan penyesuaian, mengenali sumber daya yang ada di rumah agar menjadi 
tempat yang aman dan menyenangkan bagi anak. Adapun, saran yang dikemukakan oleh Aswin Widhiyanto, sebagai berikut:

1. Untuk mengajar siswa yang berkebutuhan khusus sangatlah berbeda karena karakter dan ragam disabilitas yang berbeda-beda.

2. Pembelajaran di rumah ditekan pada bina diri tata tertib dirumah, kebesihan diri sendiri.

3. Perlu sosialisasi terkait media dan cara pembelajaran yang dilakukan kepada siswa. karena tidak semua siswa memiliki sarana terkait hal tersebut. dan tidak semua siswa tinggal bersama orang tua kandungnya.

4. Memberikan bantuan dan solusi untuk menunjang kelancaran kegiatan pembelajaran di rumah,

5. Menambah referensi pembelajaran dirumah baik model pembelajaran, strategi maupun bahan ajar terutama bagi sekolah luar biasa

6. Peningkatan kemampuan teknologi ilmu komunikasi untuk membuat strategi pembelajaran yang menarik baik dengan pelatihan mandiri ataupun yang diadakan dinas pendidikañ

7. Menyediakan media pembelajaran untuk peserta didik

8. Mendesain belajar dirumah yang bisa menjangkau ke seluruh peserta didik sesuai karakteristik.

Mekanisme penyusunan belajar dirumah dilaksanakan menyesuaikan pembelajaran individu (PPi) dengan; 1) mengidentifikasi kemampuan dan kelemahan saat ini, 2) identifikasi prioritas tujuan yang akan dicapai saat ini (disesuaikan dengan masalah kompleks anak), 3) menentukan langkah dan metode dirumah, 4) implementasi program dirumah dengan bantuan media online untuk memantau, 5) evaluasi jangka pendek dan Panjang, 6) rekomendasi prioritas program berikutnya.

Berikut pendekatan yang perlu diperhatikan oleh orang tua dalam mendampingi ABK:

1. Pengulangan, Anak diberikan contoh dan diminta untuk menirukan dan diulang terus menerus.

2. Dua arah, Dilakukan dengan perlahan dan melibatkan perasaan.

3. Suasana terkesan alami, Melakukan pembelajaran dengan membuat anak agar terkesan bahwa sedang tidak belajar.

4. Reward, Pemberian berbagai macam bentuk rewards, baik verbal maupun non verbal seperti makanan kesukaan anak. Hal ini dilakukan agar membuat anak semakin bersemangat.

5. Aktivitas bertahap, Memberikan aktivitas secara bertahap.

6. Desentisasi, Dilakukan untuk pengurangan perilaku destruktif. 


\section{KESIMPULAN}

Dalam kondisi sekarang ini semua dipaksa untuk siap menjalani semua kegiatan dari rumah termasuk pembelajaran, orangtua yang biasanya mempercayakan anaknya pada guru disekolah sekarang mendadak menjadi guru untuk anak-anaknya dirumah, bingun sudah pasti dialami karena beberapa orangtua bukan ahli dalam bidang pendidikan, ditambah lagi ada beberapa orangtua yang masih belum mengerti tentang teknologi, serta strategi-strategi yang tepat untuk PDBK.

Oleh karena itu dapat disimpulan bahwa pada masa pandemi Coronavirus Disease 2019 (COVID-19) ini mengakibatkan berbagai problematika, salah satunya di bidang pendidikan. Problematika pembelajaran di masa pandemi Coronavirus Disease 2019 (COVID-19) ini menyebabkan munculnya tantangan atau hambatan tersendiri baik bagi peserta didik berkebutuhan khusus, guru, dan orang tua. Adapun, tatangan atau hambatan tersebut, yaitu; 1) kurang siapnya guru dan orangtua dalam pembelajaran jarak jauh ini, 2) kurangnya keterampilan orangtua dalam mengakses internet, 3) rasa bosan yang muncul pada anak sehingga membuat anak malas untuk melakukan pembelajaran jarak jauh ini. Dalam menangani problematika yang muncul saat pembelajaran jarak jauh (daring), pihak sekolah terkait memiliki strategi untuk mengatasinya, berikut, 1) strategi memodifikasi program, 2) memodifikasi kurukulum, 3) memodifikasi cara pengajaran, 4) komunikasi dan, 5) fleksibilitas.

\section{SARAN}

Pemerintah diharapkan mampu lebih mempersiapkan lagi program pembelajaran dirumah serta memberikan pengetahuan tentang cara pembelajaran dirumah, pengajaran yang tepat bagi orangtua untuk mengajar anaknya dirumah termasuk anak berkebutuhan khusus. Dapat juga diadakan seminar online untuk orangtua tentang pembelajaran jarak jauh ini, dan juga tentunya melatih para pengajar agah lebih kompeten lagi dalam pelaksanaan pembelajaran jarak jauh ini. 


\section{DAFTAR PUSTAKA}

Aswin Widhiyanto. 2020. Pelaksanaan Pembelajaran Daring Bagi Individu Berkebutuhan Khusus di Indonesia.

Dewi Wahyu Aji Fatma. 2020. Dampak Covid-19 Terhadap Implementasi pembelajaran Daring di Sekolah Dasar. Edukatif: Jurnal Ilmu Pendidikan Volume 2 Nomor 1 April 2020

Drago, W. and Wagner, R. 2004. Vark preferred learning styles and online education. Management Research News. Vol. 27 No. 7. DOI: 10.1108/01409170410784211 diakses pada 25 Juni 2020

Herawati Nendeu Ineu. 2016. Pendidikan Inkulisif. https://ejournal.upi.edu/ diakses pada 25 Juni 2020

Joko Yuwono. 2012. Memahami Anak Autistik (Kajian Teoritik dan Empirik). Alfabeta: Bandung

Leonard Webster dan Patricie Metrova. 2007. Using Narrative Inquiry as a Research Method. London: Routledge.

Muhaimin, Suti'ah, dan Sugeng Listyo Prabowo. 2009. Manajemen Pendidikan. Jakarta: Kencana

Suzy Yusna Dewi. 2020. Optimalisasi Peran Guru dalam Pengayaan Kurikulum ABK Saat Sekolah Dirumah.(Directrist Ismalic Green School \& Talenta Center)

Syarifudin, Albitar Septian. 2020 . Implementasi Pembelajaran Daring Untuk Meningkatkan Mutu Pendidikan Sebagai Dampak Diterapkan Social Distancing. Jurnal pendidikan bahasa indonesia sastra : Volume 5 No 1.

Zapalska, A. and Brozik, D. 2006. Learning styles and online education. Campus-Wide Information Systems. Vol. 23 No.5. DOI: 10.1108/10650740610714080 